\title{
Dew formation on the surface of biological soil crusts in central European sand ecosystems
}

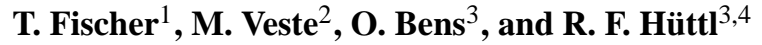 \\ ${ }^{1}$ Brandenburg University of Technology at Cottbus, Faculty of Environmental Sciences and Process Engineering, Central \\ Analytical Laboratory, Konrad-Wachsmann-Allee 6, 03046 Cottbus, Germany \\ ${ }^{2}$ CEBra - Centre for Energy Technology Brandenburg e.V., Friedlieb-Runge-Straße 3, 03046 Cottbus, Germany \\ ${ }^{3}$ GFZ German Research Centre for Geosciences, Telegrafenberg, 14473 Potsdam, Germany \\ ${ }^{4}$ Brandenburg University of Technology at Cottbus, Faculty of Environmental Sciences and Process Engineering, Chair of \\ Soil Protection and Recultivation, Konrad-Wachsmann-Allee 6, 03046 Cottbus, Germany
}

Correspondence to: T. Fischer (thomas.fischer@tu-cottbus.de)

Received: 25 June 2012 - Published in Biogeosciences Discuss.: 3 July 2012

Revised: 15 October 2012 - Accepted: 28 October 2012 - Published: 20 November 2012

\begin{abstract}
Dew formation was investigated in three developmental stages of biological soil crusts (BSC), which were collected along a catena of an inland dune and in the initial substrate. The Penman equation, which was developed for saturated surfaces, was modified for unsaturated surfaces and used for prediction of dewfall rates. The levels of surface saturation required for this approach were predicted using the water retention functions and the thicknesses of the BSCs. During a first field campaign (2-3 August 2011), dewfall increased from $0.042 \mathrm{~kg} \mathrm{~m}^{-2}$ for the initial sandy substrate to $0.058,0.143$ and $0.178 \mathrm{~kg} \mathrm{~m}^{-2}$ for crusts 1 to 3 , respectively. During a second field campaign (17-18 August 2011), where dew formation was recorded in 1.5 to $2.75-\mathrm{h}$ intervals after installation at 21:30 CEST, dewfall increased from $0.011 \mathrm{~kg} \mathrm{~m}^{-2}$ for the initial sandy substrate to 0.013 , 0.028 and $0.055 \mathrm{~kg} \mathrm{~m}^{-2}$ for crusts 1 to 3 , respectively. Dewfall rates remained on low levels for the substrate and for crust 1 , and decreased overnight for crusts 2 and 3 (with crust $3>$ crust $2>$ crust 1 throughout the campaign). Dew formation was well reflected by the model response. The suggested mechanism of dew formation involves a delay in water saturation in near-surface soil pores and extracellular polymeric substances (EPS) where the crusts were thicker and where the water capacity was high, resulting in elevated vapor flux towards the surface. The results also indicate that the amount of dewfall was too low to saturate the BSCs and to observe water flow into deeper soil. Analysis of the soil water retention curves revealed that, despite the sandy mineral matrix,
\end{abstract}

moist crusts clogged by swollen EPS pores exhibited a claylike behavior. It is hypothesized that BSCs gain double benefit from suppressing their competitors by runoff generation and from improving their water supply by dew collection. Despite higher amounts of dew, the water availability to the crust community decreases with crust development, which may be compensated by ecophysiological adaptation of crust organisms, and which may further suppress higher vegetation or mosses.

\section{Introduction}

First colonizers of new land surfaces are cryptogams, which often form biological soil crusts (BSC) covering the first millimeters of the top soil in many ecosystems from polar to desert environments. BSCs are assemblages of cyanobacteria, green algae, mosses, liverworts, fungi and/or lichens (Belnap and Lange, 2001), which stabilize the surface, redistribute water, accumulate organic matter, and which may predetermine appearance and succession of vascular plants. It has been demonstrated in this regard that water repellency, as well as reduced infiltration caused by swelling of exopolysaccharides upon rewetting, results in higher run-off during rain events (Kidron et al., 1999; Yair, 2001; Lemmnitz et al., 2008; Fischer et al., 2010), which may run-on in depressions, may supply vascular plants and may influence vegetation patterns (Yair et al., 2011; Veste et al., 2011; Fischer 
et al., 2012a). On the other hand, biological soil crusts built up by mosses limit water infiltration into deeper soil layers and reduce water availability to higher plants (Yair et al., 2011). Interaction with vascular vegetation may suppress BSCs, with shading by canopies or litter fall being possibly the most important factors for crust suppression. At the same time, availability of water to vascular plants largely depends on the form of precipitation: Rain infiltrating into the rooting zone of the soil supplies available water, while dew accumulating on leaves is - with few exceptions of desert succulents - not available to the plant metabolism. Dew has further been identified to be one of the major sources of BSC and lichen water supply under arid and semi-arid conditions (Kidron, 2000; Veste et al., 2001; Veste and Littmann, 2006). Hence, BSCs would benefit from repartitioning rain and from collecting dew.

Although the significance of dew for BSCs is emphasized in numerous studies, the influence of crust development on dew formation has received less attention. Liu et al. (2006) reported that dew deposition increased from sand and from a loamy physical crust, which they considered to be initial for crust growth, to an algal and to a moss crust. Zhang et al. (2009) described a similar pattern, where dew formation increased from bare sand to a cyanobacterial crust, to a lichen crust and to a moss crust.

We hypothesize that dew formation involves a delay in water saturation where the water capacity of the surface layer is high, resulting in elevated vapor flux towards the surface. The aim of this study is to identify the factors responsible for this delay in BSCs along a catena on an inland dune containing sandy substrate and three stages of crust development.

\section{Material and methods}

\subsection{Biological soil crusts}

The sampling site is located near Lieberose, Brandenburg, north-east Germany $\left(51^{\circ} 55^{\prime} 49^{\prime \prime} \mathrm{N}, 14^{\circ} 22^{\prime} 22^{\prime \prime} \mathrm{E}\right)$. The climate is continental with an average annual rainfall of $569 \mathrm{~mm} \mathrm{a}^{-1}$ and an average annual temperature of $8.9^{\circ} \mathrm{C}$ measured at the nearest climatic station in Cottbus. Undisturbed samples of biological soil crusts were collected in May 2010 and in July 2011 on inland sand dunes along a catena from mobile active dune to dry acidic grassland with tussocks of Corynephorus canescens. The sandy substrate was used as control. The crusts were moistened during sampling to prevent surface disruption.

On the surface of crust 1 , dominating sand grains were physically stabilized in their contact zones by accumulated organic matter and by few green algae (Zygogonium ericetorum, Klebsormidium crenulatum). The pore space was dominated by the mineral matrix. On the surface of crust 2 , the algae partially filled in the matrix pores and enmeshed sand grains. Crust 3 was characterized by intense growth of fila- mentous and coccoid algae, by few mosses (Polytrichum piliferum), which covered less than $5 \%$ of the surface, and by fungi associated with mosses. Crust organisms completely occupied the matrix pores here. All crusts were smooth and were characterized by immediate wetting when coming in contact with water drops. The repellency indices of the crusts, which were determined using the ethanol/water sorptivity method, amounted to median values of $1.01,4,89$, 9,21 and 4,98 for the substrate and for crusts 1, 2 and 3, respectively, where a theoretical value of 1 characterizes totally non-repellent soils (Hallet and Young, 1999) and exceeds 50 for highly repellent soils (Urbanek et al., 2007). A detailed description of the crusts was given by Fischer et al. (2010). The substrate was classified as carbonate-free aeolian sand with less than $4 \%$ of particles below $63 \mu \mathrm{m}$ diameter. The geometric mean particle diameter $d_{\mathrm{g}}$ was $140 \mu \mathrm{m}$. The thicknesses of crusts 1,2 and 3 were $1.5 \pm 0.5,4.0 \pm 1.0$ and $4.5 \pm 1.0 \mathrm{~mm}$, respectively.

\subsection{Water retention functions}

Water retention curves, representing both BSC and the underlying substrate, were recorded consecutively in sand (suction pressure 0 to $-0.01 \mathrm{MPa}$ ) and kaolin beds (suction pressure -0.01 to $-0.05 \mathrm{MPa}$, Eijkelkamp apparatus, The Netherlands) using $8.13 \mathrm{~cm}^{3}$ ( $\left.l_{\text {core }}=11.5 \mathrm{~mm}, 2 r=30.0 \mathrm{~mm}\right)$ steel rings, which were prepared from $250 \mathrm{~cm}^{3}$ undisturbed soil samples taken in the field. At the end of the kaolin bed experiment, the samples were air dried to constant weight at $65 \%$ relative humidity $(\mathrm{RH})$ and $20{ }^{\circ} \mathrm{C}$ (suction pressure $-58 \mathrm{MPa}$ ) and at $105^{\circ} \mathrm{C}$, which was considered to be absolute dryness. Non-crusted substrate was used as a control.

In order to retrieve corrected water retention functions of solely the BSCs, the volumetric proportion of the underlying substrate was subtracted from the total for each suction level using the water retention function of the control and the BSC thicknesses Eq. (1).

$\Theta_{\mathrm{BSC}}\left(\Psi_{i}\right)=\frac{\Theta_{\text {total }}\left(\Psi_{i}\right) V_{\text {core }}-\frac{l_{\text {core }}-l_{\text {BSC }}}{l_{\text {core }}} \Theta_{\text {Control }}\left(\Psi_{i}\right) V_{\text {core }}}{V_{\text {BSC }}}$

where $\Theta_{\mathrm{BSC}}\left(\Psi_{i}\right), \Theta_{\text {total }}\left(\Psi_{i}\right)$ and $\Theta_{\mathrm{Control}}\left(\Psi_{i}\right)$ are the volumetric water contents of the BSC, of the soil core containing both BSC and the substrate below and of the control substrate at each suction level $\Psi_{i}$, respectively; $V_{\text {core }}, 1_{\text {core }}, V_{\mathrm{BSC}}$ and $l_{\mathrm{BSC}}$ are volumes and thicknesses of the soil core and the BSCs, respectively. $V_{\mathrm{BSC}}$ was calculated using $\pi r^{2} l_{\mathrm{BSC}}$ and amounted to $1.06,2.83$ and $3.18 \mathrm{~cm}^{3}$ for crusts 1,2 and 3 , respectively. The van Genuchten function Eq. (4) was numerically fitted to these BSC water retention data.

\subsection{Dewfall}

For the determination of dewfall, the Petri dishes containing air-dry initial substrate and crusts were pushed into the ground so that their edges were close to the flat surface of 
the soil. Dew was measured in two campaigns by weighing the Petri dishes with an accuracy of $\pm 0.01 \mathrm{~g}$ (Sartorius, Germany) before the onset of dewfall (2 August 2011, 15:00) and at dawn (3 August 2011, 05:00). The second campaign took place on 17-18 August 2011, where the Petri dishes were installed at 21:30 and weighed at 23:00, 00:30, 03:00 and at 05:45 CEST. Air temperatures and relative humidities were recorded hourly at 5 and $200 \mathrm{~cm}$ above the ground; the soil temperature was recorded $5 \mathrm{~cm}$ below the surface using mercury thermometers, RH sensors (Hama, Germany), hair hygrometers and a temperature sensor (Amarell, Germany), respectively. The surface temperature of the samples was determined using an IR thermometer (Testo, Germany), where the emissivity was set to 0.95 for all samples. Wind data of a neighboring climatic station with a recording interval of $5 \mathrm{~min}$ were used for determination of aerodynamic resistances $r_{\mathrm{a}}$ (Allen et al., 1988). Because BSCs, which are considered to be the location for water phase transition in this study, reside on mineral soil and higher vegetation is absent, no boundary layer resistance $r_{t}$ for vapor flow was considered.

\subsection{Theory}

The Penman equation was developed for evaporation from saturated surfaces. Dry soils, however, behave differently, because they represent an unsaturated porous surface, which means that water is bound to the soil matrix or to EPS by capillary or osmotic forces. Heusinkveld (2008) modified the standard Penman equation for unsaturated surfaces by introducing the relative humidity $h_{\mathrm{s}}$ of the soil pores.

$L_{\mathrm{v}} E=\frac{h_{\mathrm{s}} s\left(Q^{*}-G\right)+\frac{\rho C_{p}}{r_{\mathrm{at}}}\left(h_{\mathrm{s}} e_{\mathrm{W}}(T)-e\right)}{h_{\mathrm{s}} s+\gamma}$

where $L_{\mathrm{v}} E$ is the latent heat flux $\left(\mathrm{W} \mathrm{m}^{-2}\right.$, or $\left.\mathrm{J} \mathrm{m}^{-2} \mathrm{~s}^{-1}\right), h_{\mathrm{s}}$ is the relative humidity of the soil pores, $s$ is the derivative of the saturated vapor pressure $\left(\mathrm{Pa} \mathrm{K}^{-1}\right), Q^{*}$ is the net radiation and $G$ is the soil heat flux $\left(\mathrm{W} \mathrm{m}^{-2}\right), \rho$ is the density of air $\left(\mathrm{kg} \mathrm{m}^{-3}\right), C_{p}$ is the specific heat of air at constant pressure $\left(\mathrm{J} \mathrm{kg}^{-1} \mathrm{~K}^{-1}\right), r_{\mathrm{at}}$ is the sum of the aerodynamic plus the boundary layer resistances $\left(\mathrm{s} \mathrm{m}^{-1}\right), e_{\mathrm{w}}(T)$ is the saturated vapor pressure at reference height $(\mathrm{Pa}), e$ is the vapor pressure at reference height $(\mathrm{Pa})$ and where $\gamma$ is the psychrometric constant $\left(66 \mathrm{~Pa} \mathrm{~K}^{-1}\right)$.

The Penman equation can also be used to describe the process reverse to evaporation: surface condensation, or dewfall. In contrast to the standard Penman equation, where dew formation on a free water surface is reduced by the second term of Eq. (2), under dry soil conditions the dew formation will be enhanced, because the saturation deficit of the atmospheric surface layer rarely approaches zero (Heusinkveld, 2008). In addition, soil pores fill with water as dew enters the surface, resulting in an increase of $h_{\mathrm{S}}$ over time. Assuming increasing water capacity with crust devel- opment, we hypothesize that dew formation increases, because water saturation in pores will be reached later in time when the soil water capacity is high, which will prolongate the vapor flux towards the surface. The question arises as to what factors control dew formation in porous layers, as in BSCs in particular, when considering this kinetic component during dewfall.

To determine the dewfall rate $\mathrm{d} D / \mathrm{d} t$ in $\mathrm{kg} \mathrm{m}^{-2} \mathrm{~s}^{-1}$, Eq. (2) was rewritten to Eq. (3).

$$
\begin{aligned}
\frac{M_{\mathrm{H}_{2} \mathrm{O}} L_{\mathrm{v}} E}{\Delta H_{\mathrm{vap}}} & =\frac{\mathrm{d} D}{\mathrm{~d} t} \\
& =\frac{h_{\mathrm{s}} s\left(Q^{*}-G\right)+\frac{\rho C_{p}}{r_{\mathrm{a}}}\left(1-h_{\mathrm{s}}\right) e_{\mathrm{w}}(T)}{h_{\mathrm{s}} s+\gamma} \cdot \frac{M_{\mathrm{H}_{2} \mathrm{O}}}{\Delta H_{\mathrm{vap}}}
\end{aligned}
$$

where $1-h_{\mathrm{S}}$ is the water saturation deficit in the soil pores, $M_{\mathrm{H}_{2} \mathrm{O}}$ is the molecular weight $\left(0.018 \mathrm{~kg} \mathrm{~mol}^{-1}\right)$ and $\Delta H_{\text {vap }}$ is the condensation heat of water $\left(44 \mathrm{~kJ} \mathrm{~mol}^{-1}\right.$ at $\left.20^{\circ} \mathrm{C}\right)$. $Q^{*}$ was assumed to equal $0 \mathrm{~W} \mathrm{~m}^{-2}$ (nighttime). The thermal properties of the crusts are described in Appendix A. For simplicity, it was also assumed that $1 \mathrm{~m}^{3}$ water equals $1000 \mathrm{~kg}$.

The van Genuchten function was used for water retention curve fit (van Genuchten, 1980; Eq. 4).

$\Theta\left(\Psi_{\mathrm{M}}\right)=\Theta_{\mathrm{r}}+\frac{\Theta_{\mathrm{s}}-\Theta_{\mathrm{r}}}{\left[1+\left(\alpha \Psi_{\mathrm{M}}\right)^{n}\right]^{1-n^{-1}}}$

where $\Psi_{\mathrm{M}}$ is the soil water potential $(\mathrm{hPa}), \Theta_{\mathrm{r}}$ and $\Theta_{\mathrm{S}}$ are the residual and saturated volumetric water contents $\left(\mathrm{m}^{3} \mathrm{~m}^{-3}\right)$ of the crust, respectively, and where the parameters $\alpha\left(\mathrm{in} \mathrm{cm}^{-1}\right)$ and $n$ are related to the inverse of the air entry suction as well as the pore size distribution, respectively. $\Psi_{\mathrm{M}}$ is related to $h_{\mathrm{s}}$ in Eq. (5) (Lal and Shukla, 2004).

$h_{\mathrm{s}}=\exp \left(\Psi_{\mathrm{M}} \frac{M_{\mathrm{H}_{2} \mathrm{O}}}{R T}\right)$

where $R$ is the specific gas constant $\left(462 \mathrm{~J} \mathrm{~kg}^{-1} \mathrm{~K}^{-1}\right)$ and $T$ is the surface temperature $(\mathrm{K})$.

We predicted BSC dewfall $D$ (in $\mathrm{m}^{3} \mathrm{~m}^{-2}$ ) in 1-h intervals by numerically integrating Eq. (3) over time, which was then used to calculate the increase of the volumetric water content $\Theta\left(t_{i}+1\right)$ using Eq. (6), and which resulted in a crust-specific response in $\Psi_{\mathrm{M}}$ (using Eq. 4) and in $h_{\mathrm{s}}$ (using Eq. 5).

$\Theta\left(t_{i}+1\right)=\Theta\left(t_{i}\right)+\frac{D_{i}}{l_{\mathrm{BSC}}}$

where $l_{\mathrm{BSC}}$ is the BSC thickness in $\mathrm{m}$.

This algorithm was repeated for the following 1-h intervals by consecutively using $h_{\mathrm{s}}$ predicted with Eq. (5) as well as the meteorological data recorded in the field in Eq. (3). The R software suite was used for the calculations. We used 1 -h time steps because it is well acknowledged that the Penman equation generates some overall error for shorter time intervals (Davie, 2008). 
Table 1. van Genuchten fitting parameters of the corrected BSC water retention functions, $\Theta$ in $\mathrm{m}^{3} \mathrm{~m}^{-3}$, unit of $-\Psi$ in regression analysis was $\mathrm{hPa}$.

\begin{tabular}{lrrrr}
\hline & $\Theta_{\mathrm{r}}$ & $\Theta_{\mathrm{s}}$ & $\alpha$ & $n$ \\
\hline Substrate & 0.006 & 0.34 & 0.0380 & 2.48 \\
Crust 1 & 0.000 & 0.67 & 0.0036 & 1.97 \\
Crust 2 & 0.030 & 0.73 & 0.0012 & 1.80 \\
Crust 3 & 0.005 & 0.85 & 0.0060 & 1.64 \\
\hline
\end{tabular}

We found previously patchy distributions of the BSCs over the soil surface (Fischer et al., 2012a). Soil water retention functions, however, were determined in steel rings, which had an inner diameter of $30 \mathrm{~mm}$ (see Sect. 2.3) and which were taken at locations with dense crust cover (crust 1) or from within individual BSC patches (crusts 2 and 3). The Petri dishes, which were used for determination of dewfall, had a diameter of $10 \mathrm{~cm}$ and were not covered entirely with BSCs. Assuming sandy substrate in the crust patch interspaces, we accounted for incomplete crust coverage by weighing individual contributions of BSCs and substrate to total dewfall using Eq. (7).

$D_{\mathrm{w}}=c_{\mathrm{BSC}} D_{\mathrm{BSC}}+\left(1-c_{\mathrm{BSC}}\right) D_{\text {Substrate }}$

where $D_{\mathrm{w}}$ is the weighed hourly dewfall, $\mathrm{c}_{\mathrm{BSC}}$ is the crust coverage $(0.2,0.4$ and 0.7 for crusts 1,2 and 3 , respectively), $D_{\mathrm{BSC}}$ and $D_{\text {Substrate }}$ are hourly dewfall values for BSC patches and for the substrate, respectively. Cumulative dewfall was determined as the sum of hourly dewfall values.

The model error was determined for each crust by calculating the root-mean-square error (RMSE) using Eq. (8).

$\mathrm{RMSE}=\sqrt{\frac{1}{n-1} \sum_{i=1}^{n}\left(D_{\text {field }}-D_{\text {pred }}\right)^{2}}$

where $D_{\text {field }}$ and $D_{\text {pred }}$ are dewfall rates determined in the field and predicted by the model, respectively.

\section{Results}

The corrected water retention functions of the BSCs and the corresponding van Genuchten fitting parameters are shown in Fig. 1 and in Table 1, respectively.

During the first field campaign (2-3 August 2011), dewfall increased with crust development from $0.042 \mathrm{~kg} \mathrm{~m}^{-2}$ for the initial sandy substrate to $0.058,0.143$ and $0.178 \mathrm{~kg} \mathrm{~m}^{-2}$ for crusts 1 to 3 , respectively. During the second field campaign (17-18 August 2011), dewfall increased with crust development from $0.011 \mathrm{~kg} \mathrm{~m}^{-2}$ for the initial sandy substrate to $0.013,0.028$ and $0.055 \mathrm{~kg} \mathrm{~m}^{-2}$ for crusts 1 to 3 , respectively (Fig. 2). The predicted by the model values correlated significantly $\left(r^{2}=0.97, p<0.001\right)$ with the field data, but the model tended to underestimate dewfall rates.

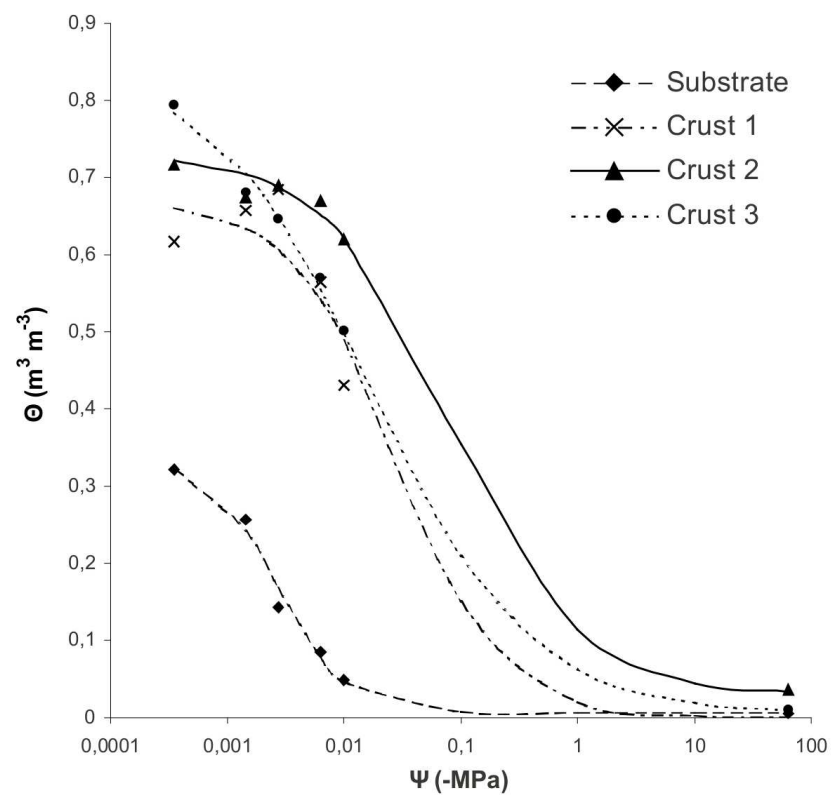

Fig. 1. Water retention curves of the initial substrate and the BSCs. $\Psi$ is the soil water potential; $\Theta$ is the volumetric water content. Arithmetic mean values with $n=3$.

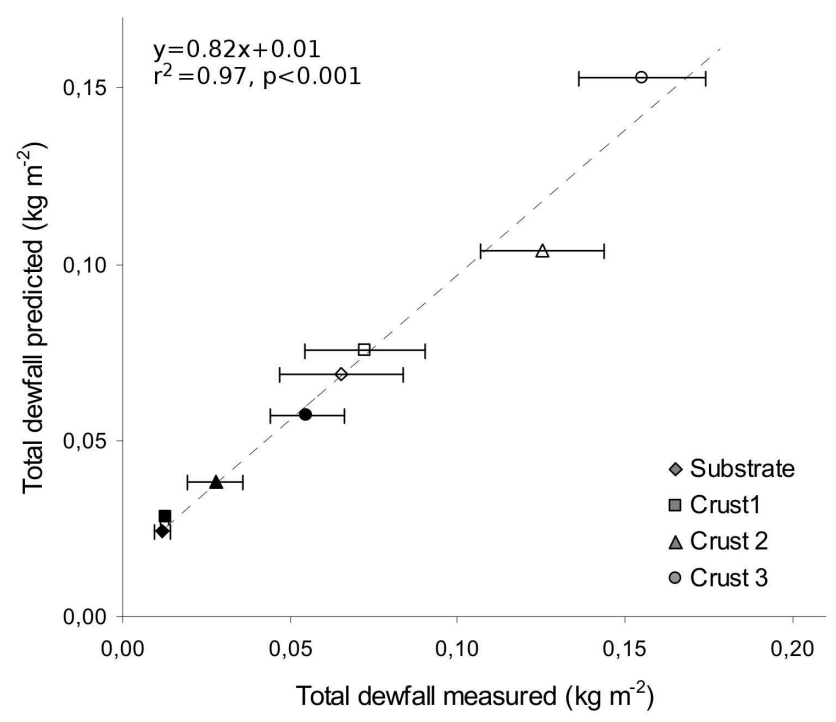

Fig. 2. Measured and predicted amounts of cumulative dew in the initial substrate and in the crusts 1, 2 and 3; 2-8 August 2011 (blank symbols) and 17-18 August 2011 (filled symbols). Arithmetic mean values with $n=3$; error bars indicate standard deviation.

Measured dewfall rates (Fig. 3, symbols) increased from the substrate to crusts 1, 2 and 3 at 23:00 CEST during the second field campaign. While they remained on low levels for the substrate and for crust 1, they started at higher levels and decreased continuously overnight for crusts 2 and 3 (with crust $3>$ crust $2>$ crust 1 throughout the campaign). Dewfall rates predicted by the model (Fig. 3 , lines) started at 


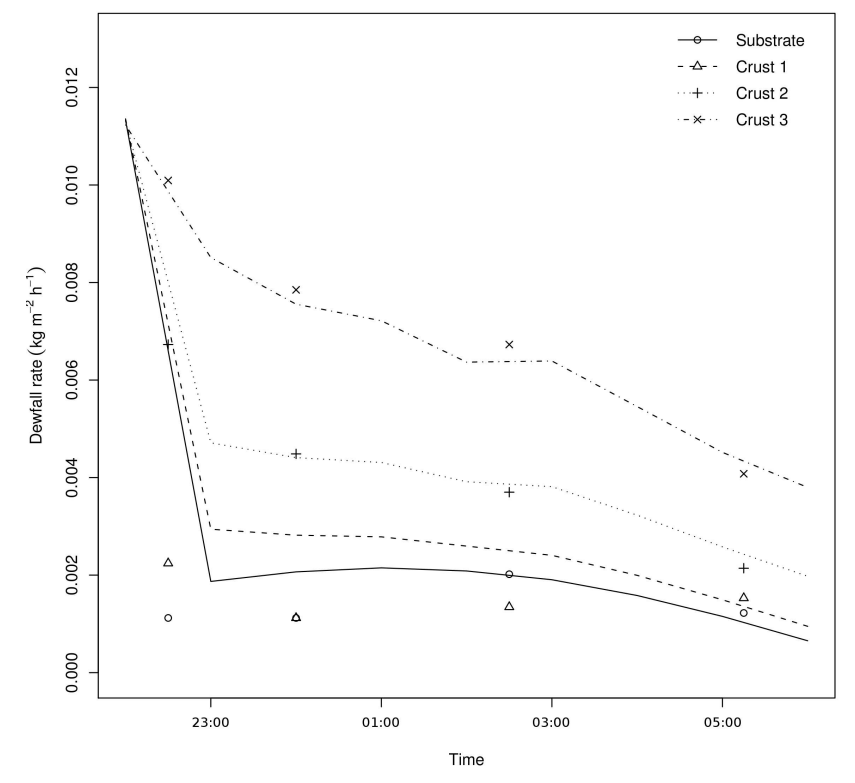

Fig. 3. Dewfall rate over time for the substrate and for the crusts 1, 2 and 3. Recording date: 17-18 August 2011. Symbols represent measured values; lines represent the model response, $n=3$.

approximately $0.012 \mathrm{~kg} \mathrm{~m}^{-2} \mathrm{~h}^{-1}$ for all crusts one hour after installation (at 22:30 CEST) and then followed the course of the field data. The RMSE was similar for all crusts and ranged between 0.0008 and $0.0013 \mathrm{~kg} \mathrm{~m}^{-2} \mathrm{~h}^{-1}$.

Maximum dawning suction pressures were observed during the first field campaign and amounted to -0.005 $(\mathrm{pF}=1.71),-0.631 \quad(\mathrm{pF}=3.80),-2.00 \quad(\mathrm{pF}=4.30)$ and $-1.58 \mathrm{MPa}(\mathrm{pF}=4.20)$ in the initial substrate and in crusts 1 to 3 , respectively, where the moistened layer of the substrate was assumed to be $0.5 \mathrm{~mm}$ thick. Therefore, we did not observe soil water discharge into depth in this study. Instead, the BSCs formed a moist layer over dry sand when dewfall ceased in the morning, even at higher precipitation (Fig. 4).

\section{Discussion}

Although the sandy mineral matrix did not differ between the crusts, the van Genuchten parameter $n$ decreased from the control substrate to the moist crusts 1,2 and 3 (Table 1), thereby exhibiting a clay-like behavior. Moistening of the crusts for water retention measurements obviously led to clogging of soil pores through swelling of EPS (Fischer et al., 2010).

The saturated volumetric water content $\Theta_{\mathrm{S}}$ amounted to a typical for sand value of 0.34 , but increased to atypically high for mineral soils values of $0.67,0.73$ and 0.85 for crusts 1,2 and 3, respectively (Table 1). This increase in water holding capacity reflects the progressing occupation of the surface substrate with organic matter: The initial substrate did not significantly contain organic components, which gained in

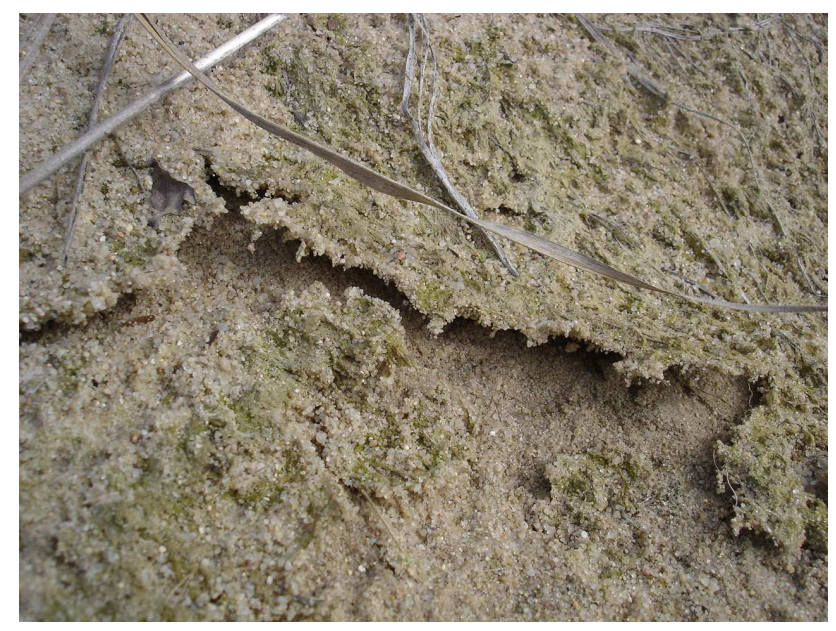

Fig. 4. Crust 2 after drizzling rain in the morning. BSCs formed a moist layer over loose dry sand, so that no water flow into deeper soil could be observed. Image: Maik Veste, 21 May 2008.

importance as the matrix pores became occupied by crust organisms and by EPS. The data reported by Chenu (1993) for sand-polysaccharide mixtures support our approach of using the van Genuchten function, which have been demonstrated to be comparable with BSCs (Fischer et al., 2010).

The main sources of moisture for dew formation on the soil surface are the free atmosphere and moist deeper soil (Garrett and Segal, 1988; Littmann and Veste, 2008). By placing the BSCs into Petri dishes in this study, the crust surface was exposed to the free atmosphere only, while the influence of deep soil moisture on dew formation was excluded. Hence, only aboveground atmospheric conditions were relevant for dew formation here.

Dewfall sums and rates predicted by the proposed model corresponded well with the field data (Figs. 2 and 3). The initial value, amounting to approximately $0.012 \mathrm{~kg} \mathrm{~m}^{-2} \mathrm{~h}^{-1}$, was predicted to be identical for all samples, because an identical soil water potential was assumed for all samples at the beginning of each experiment. The dewfall rate of the substrate dropped rapidly (within the first time step of modeling) to approximately $0.002 \mathrm{~kg} \mathrm{~m}^{-2} \mathrm{~h}^{-1}$, which is an indication of rapid water saturation at the surface. Water adsorption by the BSCs resulted in a saturation delay, which increased from crust 1 to crust 3 and which further resulted in higher dew formation over time with crust development.

We did not observe an influence of elevated repellency indices on dew formation. Water repellency typically occurs on very dry surfaces. It well might be that a slow increase of the relative humidity near the ground and in soil pores, which is typical before dew starts to form after sunset, causes hydration of polysaccharides, thus preconditioning the surface for later liquid water adsorption (Fischer et al., 2012b).

Liu et al. (2006) and Zhang et al. (2009) reported increasing dewfall with crust development, which can be confirmed 
by our data. Because the thermodynamic and meteorological datasets used for the modeling were identical for all crusts, it can be deduced that dew formation depended on their water retention properties (see Table 1), and that it increased with BSC thickness and coverage

Davis et al. (2010) reported that rain amounts below $1 \mathrm{~mm}$ did not saturate the surface. In our study, the highest amounts of dew never exceeded $0.2 \mathrm{~mm}$. The dawning water potentials decreased with BSC thickness, reaching maximal values of $-0.005,-0.631,-2.00$ and $-1.58 \mathrm{MPa}$ in the initial substrate and in crusts 1 to 3 , respectively. Swift et al. (1979) reported that bacteria are inactive below -1.0 to $-1.5 \mathrm{MPa}$ in soils, whereas soil fungi are active down to $-15 \mathrm{MPa}$, and that some Aspergillus and Penicillium are active to $-40 \mathrm{MPa}$ and below. Fischer (2009) reported that soil respiration amounted to approx. 5-8\% of maximal respiration at $-1.5 \mathrm{MPa}$, indicating still ongoing microbial activity under conditions of plant wilting. Moore (1986) found for leaf and needle litter that decomposition will cease at $-38 \mathrm{MPa}$. Palmer and Friedman (1990) reported soil water potential tolerances of cryptoendolithic lichens that begin to photosynthesize at a matric water potential $>-46.4 \mathrm{MPa}$. Cyanolichens and free-living cyanobacteria need liquid water for the activation of photosynthesis (Lange et al., 1993, 1998). Contrarily, the photosynthesis metabolism of green-algae and green algae soil lichens as well as of dry Microcoleus sociatus is reactivated solely by hydration in equilibrium with high air humidity (Lange et al., 1994; Lange, 2001). Lange et al. (1992) and Veste et al. (2001) estimated that BSCs are photosynthetically active at precipitation amounts $>0.1 \mathrm{~mm}$, which is similar to the dewfall amounts reported in our field experiment (Fig. 2).

Due to water retention by EPS, the onset of the phase transition from vapor to liquid water more resembles vapor adsorption rather than surface condensation. Hence, rapid adsorption of freshly condensed water by dry EPS prevents the formation of free surface water films, which are, for example, necessary for cyanobacterial activity. Because delayed water saturation of thicker crusts most likely affects the metabolic activity of crust organisms, it can be assumed that some adaptation of the crust community is likely to occur. Furthermore, the water holding capacity of the BSCs may also influence the duration of BSC wetting and of the photosynthetic activity during daytime. In combination with micro-scale differences of the microclimate (Kidron et al., 2000, Veste et al., 2006), these are important feedback mechanisms for the development of the different crust stages.

\section{Conclusions}

The proposed mechanism of dew formation involves later water saturation in near-surface soil pores and EPS where the crusts are thicker and where the water capacity is high, resulting in elevated vapor flux towards the surface. This applies to both the free atmosphere as well as to the deeper soil, possibly also resulting in some extraction of moisture from the rooting zone of higher plants and its capture in BSCs. Unlike vascular plants, it can be hypothesized that BSCs gain benefit from improving their water supply by dew collection. Despite higher amounts of dew, the water availability to the crust community decreases with crust development. It can be concluded that under constant further conditions organic matter accumulation, crust thickness and coverage were the main factors of dew formation.

\section{Appendix A}

\section{Thermal properties of the crusts}

The soil heat flux $\mathrm{G}$ over time was described as a sine wave (Horton and Wierenga, 1983) using Eq. (A1).

$$
\begin{aligned}
G(z, t)= & A_{T} C \sqrt{\omega \alpha_{\mathrm{STC}}} \cdot \exp \left(-z \sqrt{\frac{\omega}{2 \alpha_{\mathrm{STC}}}}\right) \\
& \cdot \sin \left(\omega t+\phi+\frac{\pi}{4}-z \sqrt{\frac{\omega}{2 \alpha_{\mathrm{STC}}}}\right)
\end{aligned}
$$

where $A_{T}$ is the amplitude of the soil surface temperature $(\mathrm{K}), C$ is the volumetric heat capacity $\left(\mathrm{J} \mathrm{m}^{-3} \mathrm{~K}^{-1}\right), \omega$ is the angular frequency, $\alpha_{\mathrm{STC}}$ is the soil thermal conductivity $\left(\mathrm{W} \mathrm{m}^{-1} \mathrm{~K}^{-1}\right), \Phi$ is the phase angle and $z$ is the soil depth (5 mm). $\omega$ and $\Phi$ were fit numerically to generate a $G(t)$ maximum at 13:00 CEST and a period of $24 \mathrm{~h}$.

The de Vries model, which has attracted considerable attention to describe the soil thermal conductivity, is based on the assumption that soil particles and air are immersed in a continuous medium: water (de Vries, 1963). Because this assumption does not apply to dry soils, we calculated the soil thermal conductivity of the dry samples using Eq. (A2) (Johansen, 1975).

$\alpha_{\mathrm{STC}}=\frac{0.135 \rho_{\mathrm{d}}+64.7}{\rho_{\mathrm{s}}-0.947 \rho_{\mathrm{d}}}$

where $\rho_{\mathrm{d}}$ is the bulk density of the crust and $\rho_{\mathrm{S}}$ is the density of quartz $\left(\mathrm{kg} \mathrm{m}^{-3}\right)$.

The soil heat capacity $C$ was determined according to de Vries (1963) using Eq. (A3).

$C=2.0 \cdot x_{\mathrm{s}}+2.51 \cdot x_{\mathrm{o}}+4.19 \cdot \Theta\left(t_{i}\right)$

where $x_{\mathrm{s}}, x_{\mathrm{o}}$ and $\Theta\left(t_{i}\right)$ are the volumetric contributions of mineral (derived from the water retention curve) and organic components (as loss on ignition; 0,42, 0.90 and $3.08 \%$ for crusts 1, 2 and 3, respectively), and the volumetric moisture content after $i$ hours $\left(\mathrm{m}^{3} \mathrm{~m}^{-3}\right)$, which was derived from the model output. 
Acknowledgements. This study is part of the Transregional Collaborative Research Centre 38 (SFB/TR 38), which is financially supported by the Deutsche Forschungsgemeinschaft (DFG, Bonn) and the Brandenburg Ministry of Science, Research and Culture (MWFK, Potsdam). The authors thank Horst Gerke (ZALF Müncheberg), Xiao Bo (BTU Cottbus) for their kind review of the manuscript, Wolfgang Wieprecht, Uwe Zeihser, Philipp Lange (BTU Cottbus) and Matthieu Lae (Ecole des Mines Douai, France) for technical assistance. The authors are grateful to Aaron Yair (Hebrew University Jerusalem) and to an anonymous reviewer for their truly helpful comments.

Edited by: W. Gerwin

\section{References}

Allen, R. G., Pereira, L. S., Raes, D., and Smith, M.: Crop evapotranspiration - Guidelines for computing crop water requirements - FAO Irrigation and drainage paper 56, FAO - Food and Agriculture Organization of the United Nations, Rome, 1988.

Belnap, J. and Lange, O. L. (Eds.): Biological soil crusts: structure, function and management. Ecol. Studies 150, Springer, Heidelberg-Berlin-New York, 503 pp., 2001.

Chenu, C.: Clay or sand polysaccharide associations as models for the interface between micro-organisms and soil: Water related properties and microstructure, Geoderma, 56, 143-156, 1993.

Davie, T.: Fundamentals of Hydrology, Taylor and Francis e-library, 2008.

Davis, W. L., de Pater, I., and McKay, C. P.: Rain infiltration and crust formation in the extreme arid zone of the Atacama Desert, Chile, Planet. Space Sci., 58, 616-622, 2010

De Vries, D. A.: Thermal properties of soils, in: Physics of plant environment, edited by: Van Wijk, W. R., North Holland Publishing Company, Amsterdam, 210-235, 1963.

Fischer, T.: Substantial rewetting phenomena on soil respiration can be observed at low water availability, Soil Biol. Biochem., 41, 1577-1579, 2009.

Fischer, T., Veste, M., Wiehe, W., and Lange, P.: Water repellency and pore clogging at early successional stages of microbiotic crusts on inland dunes, Brandenburg, NE Germany, Catena, 80, 47-52, 2010.

Fischer, T., Veste, M., Eisele, A., Bens, O., Spyra, W., and Hüttl, R. F.: Small scale spatial heterogeneity of Normalized Difference Vegetation Indices (NDVIs) and hot spots of photosynthesis in biological soil crusts, Flora, 207, 159-167, 2012a.

Fischer, T., Yair, A., Veste, M., Geppert, H.: 13C-CP/MAS-NMR as related to hydraulic properties of biological soil crusts on sand dunes: a comparison between an arid and a temperate sites, Ecol. Process., submitted, 2012b.

Garrett, J. R. and Segal, M.: On the contribution of atmospheric moisture to dew formation, Bound.-Lay. Meteorol., 45, 209-236, 1988.

Hallet, P. D. and Young, I. M.: Changes to water repellence of soil aggregates caused by substrate-induced microbial activity, Eur. J. Soil Sci., 50, 35-40, 1999.

Heusinkveld, B. G.: On dew and micrometeorology in an arid coastal ecosystem, Ph.D. thesis, Wageningen University, The Netherlands, Koninklijke Bibliotheek, Den Haag, 2008.
Horton, R. and Wierenga, P. J.: Estimating the soil heat flux from observations of soil temperature near the surface, Soil Sci. Soc. Am. J., 47, 14-20, 1983.

Johansen, O.: Thermal conductivity of soils, Ph.D. thesis, Trondheim, Norway, 1975, CRREL TL 637, available at: http://www. dtic.mil/ (last access: 03 September 2012), 1975.

Kidron, G. J.: Analysis of dew precipitation in three habitats within a small arid drainage basin, Negev Highlands, Israel, Atmos. Res., 55, 257-270, 2000.

Kidron, G. J., Yaalon, D. H., and Vonshak, A.: Two causes for runoff initiation on microbiotic crusts: Hydrophobicity and pore clogging, Soil Sci., 164, 18-27, 1999.

Kidron, G. J., Barzilay, E., and Sachs, E.: Microclimate control upon sand microbiotic crusts, western Negev Desert, Israel, Geomorphology, 36, 1-18, 2000.

Lal, R. and Shukla, M. K.: Principles of soil physics, Marcel Dekker, New York, 717 pp., 2004.

Lange, O. L.: Photosynthesis of soil-crust biota as dependent on environmental factors, in: Ecol. Studies 150, Belnap, J. and Lange, O., Springer, Heidelberg-Berlin-New York, 218-240, 2001.

Lange, O. L., Kidron, G. J., Büdel, B., Meyer, A., Killian, E., and Abeliovich, A.: Taxonomic composition and photosynthetic characteristics of the biological soil crusts covering sand dunes in the western Negev, Funct. Ecol., 6, 519-527, 1992.

Lange, O. L., Büdel, B., Meyer, A., and Killian, E.: Further evidence that activiation of net photosynthesis by dry cyanobacterial lichens requires liquid water, Lichenologist, 25, 175-189, 1993.

Lange, O. L., Meyer, A., and Büdel, B.: Net photosynthesis activation of a desiccated cyano-bacterium without liquid water in high air humidity alone. Experiments with Microcoleus sociatus isolated from a desert soil crust, Funct. Ecol., 8, 52-57, 1994.

Lange, O. L., Belnap, J., Reichenberger, H.: Photosynthesis of the cyanobacterial soil-crust lichen Collema tenax from arid lands in southern Utah, USA: role of water content on light and temperature responses of $\mathrm{CO}_{2}$ exchange, Funct. Ecol., 12, 519-527, 1998.

Lemmnitz, C., Kuhnert, M., Bens, O., Güntner, A., Merz, B., and Hüttl, R.: Spatial and temporal variations of soil water repellency and the influence on surface runoff, Hydrol. Process., 22, 19761984, 2008

Littmann, T. and Veste, M.: Evapotranspiration, transpiration and dewfall, in: Arid Dune Ecosystems - The Nizzana Sands in the Negev Desert, edited by: Yair, S.-W., Veste, A., Breckle, M., Ecological Studies 200, Springer, Berlin Heidelberg New York, 183200, 2008.

Liu, L. C., Li, S. Z., Duan, Z. H., Wang, T., Zhang, Z. S., and Li, X. R.: Effects of microbiotic crusts on dew deposition in the restored vegetation area at Shapotou, northwest China, J. Hydrol., 328, 331-337, 2006.

Moore, A. M.: Temperature and moisture dependence of decomposition rates of hardwood and coniferous leaf litter, Soil Biol Biochem., 18, 427-435, 1986.

Palmer, R. J. and Friedmann, E. I.: Water relations and photosynthesis in the cryptoendolithic microbial habitat of hot and cold deserts, Microb. Ecol., 19, 111-118, 1990.

Swift, M. J., Heal, O. W., and Anderson, J. M.: Decomposition in Terrestrial Ecosystems, University of California Press, Berkeley, 372 pp., 1979. 
Urbanek, E., Hallett, P., Feeney, D., and Horn, R.: Water repellency and distribution of hydrophilic and hydrophobic compounds in soil aggregates from different tillage systems, Geoderma, 140, 147-155, 2007.

van Genuchten: A closed-form equation for predicting the hydraulic conductivity of unsaturated soils, Soil Sci. Soc. Am. J., 44, 892898, 1980.

Veste, M. and Littmann, T.: Dewfall and its geo-ecological implication for biological surface crusts in desert sand dunes (northwestern Negev, Israel), J. Arid Land Stud., 16, 139-147, 2006.

Veste, M., Littmann, T., Friedrich, H., and Breckle, S.-W.: Microclimatic boundary conditions for activity of soil lichen crusts in sand dunes of the north-western Negev desert, Israel, Flora, 196, 465-476, 2001.
Veste, M., Breckle, S.-W., Eggert, K., and Littmann, T.: Vegetation pattern in arid sand dunes controlled by biological soil crusts along a climatic gradient in the Northern Negev desert, Basic Appl. Dryland Res., 5, 1-16, 2011.

Yair, A.: Effects of biological soil crusts on water redistribution in the Negev Desert, Israel: a case study in longitudinal dunes, in: Ecol. Studies 150, edited by: Belnap, J. and Lange, O., Springer, Heidelberg-Berlin-New York, 303-314, 2001.

Yair, A., Almong, R., and Veste, M.: Differential hydrological response of biological topsoil crusts along a rainfall gradient in a sandy arid area: Northern Negev desert, Israel, Catena, 87, 326333, 2011.

Zhang, J., Zhang, Y. M., Alison, D., Cheng, J. H., Zhou, X. B., and Zhang, B. C.: The influence of biological soil crusts on dew deposition in Gurbantunggut Desert, Northwestern China, J. Hydrol., 379, 220-228, 2009. 